ББК 67.91

\title{
МИНИСТЕРСТВО ЮСТИЦИИ РОССИЙСКОЙ ФЕДЕРАЦИИ В ПРОЦЕССЕ ЗАКЛЮЧЕНИЯ МЕЖДУНАРОДНЫХ ДОГОВОРОВ
}

\author{
(c) 2020 Курашвили Автандил Юрьевич
}

кандидат юридических наук, заместитель начальника отдела правовой экспертизы договоров компании «Газпром ЭП Интернэшнл Сервисиз Б. В.», филиал в Санкт-Петербурге

E-mail: avtand-reserv@yandex.ru

Статья посвящена участию Министерства юстиции Российской Федерации в процессе заключения международных договоров. Минюст России может способствовать решению многих правовых задач, в том числе международных, что является особо важным аспектом для полноценного исполнения в будущем принимаемых государством договорных обязательств. На законодательном уровне министерство наделено существенными правами в сфере международных договоров. Однако, подзаконные акты, призванные конкретизировать и развить данные права, в полной мере с такой задачей не справляются. В результате возникает целый ряд коллизий, которые в дальнейшем необходимо разрешать по общим правилам преодоления юридических коллизий. Автором рассмотрены процедурные вопросы по заявленной теме и выявлены основные проблемы и противоречия. Публикация может представлять интерес для лиц, занимающихся правом международных договоров, процедурой заключения международных договоров, а также полномочиями министерств и ведомств Российской Федерации по обозначенному вопросу.

Ключевые слова: Министерство юстиции, международные договоры, заключение договоров, правовые коллизии, межведомственные договоры.

В современном международном праве договоры играют одну из главных ролей, вытесняя обычное право практически из всех сфер регулирования. Они представляют собой наиболее приемлемую и апробированную веками модель согласования, закрепления и развития сотрудничества между государствами и народами. Основная задача международных договоров заключается в формализованной фиксации взаимных прав и обязанностей договаривающихся сторон. Международные договоры призваны гарантировать в международных отношениях стабильность и преемственность установленного правопорядка.

Целью данного исследования является анализ внутригосударственной правовой базы, регулирующей участие Министерства юстиции Российской Федерации (далее также Минюст России или Министерство) в процессе заключения международных договоров, как организационной структуры, имеющей свою специфику.

В соответствии с Положением о Министерстве юстиции Российской Федерации, Министерство является федеральным органом исполнительной власти [13, п. 1], наделенным определенными полномочиями в сфере между- народных отношений в целом, и международных договоров, в частности.

Основными внутригосударственными актами, регулирующими участие Минюста России в процессе заключения международных договоров, являются: Федеральный закон «О международных договорах Российской Федерации» [14], Указ Президента «Вопросы Министерства юстиции Российской Федерации», утвердивший Положение о Минюсте России [13], а также Приказ Минюста России «Об утверждении Регламента Министерства юстиции Российской Федерации» [6].

Федеральный закон «О международных договорах Российской Федерации» определил процедуры по подготовке, заключению, исполнению и прекращению международных договоров, закрепил полномочия и компетенцию государственных органов и высших должностных лиц в отношении таких договоров, а также установил трехуровневую систему международных соглашений, которые представлены межгосударственными и межправительственными договорами, а также договорами межведомственного характера [14, п. 2 ст. 3].

Указ Президента «Вопросы Министерства юстиции Российской Федерации», несмотря на 
свой объем, содержит незначительное количество положений, касающихся заключения международных договоров.

Еще меньше таких норм можно найти в Приказе Минюста России «Об утверждении Регламента Министерства юстиции Российской Федерации».

Исходя из логического и систематического толкования положений Федерального закона и Указа Президента, участие Минюста России в процессе заключения международных договоров можно подразделить на два основных направления. В первом случае Министерство выступает в качестве экспертной организации, а также от лица государства подписывает международный договор межведомственного характера, как это предусмотрено пунктом 3 статьи 11 Федерального закона. Во втором случае Минюст России является только уполномоченной экспертной организацией в соответствии со статьей 10 того же закона, а подписание производят вышестоящие государственные органы.

В отношении первого направления необходимо отметить, что международные договоры межведомственного характера образуют специализированную юридическую основу межгосударственных отношений по вопросам компетенции соответствующих министерств и ведомств.

На ведомственном уровне Минюст России в части международных договоров заключает соответствующие двусторонние [7; 9] и многосторонние соглашения [8; 10] по общим вопросам правового сотрудничества и правовой помощи.

Такая возможность предусмотрена как Федеральным законом, так и Положением о Минюсте России. Но, к сожалению, формулировки соответствующих пунктов Положения носят рамочный и весьма неконкретный характер. Например, в целях реализации своих полномочий Минюст России имеет право «заключать в соответствии с законодательством Российской Федерации международные договоры Российской Федерации межведомственного характера по вопросам, относящимся к установленной сфере деятельности» [13, п/п. 6 п. 8]. Бо́льшей конкретики не приводится.

Также, при рассмотрении правовых положений о международных договорах, заключаемых министерствами и ведомствами Российской Федерации, обращает на себя внимание одна особенность. В соответствии с Федеральным зако- ном федеральный министр, руководитель иного органа исполнительной власти в пределах своей компетенции вправе вести переговоры и подписывать международные договоры межведомственного характера без предъявления полномочий [14, п. 3 ст. 12]. Однако, Венская конвенция 1969 года о праве международных договоров не дает права осуществлять действия по заключению международных договоров без предъявления полномочий какому-либо из министров, кроме министра иностранных дел [2, п. 2 ст. 7].

Как правило, решения о проведении переговоров о заключении международных межведомственных договоров принимаются Правительством Российской Федерации. После принятия положительного решения на правительственном уровне, вопрос о подписании международного договора межведомственного характера делегируется министру юстиции России, который в рамках своей компетенции вправе подписать договор без предъявления полномочий [14, п. 3 ст. 11].

На наш взгляд справедливо отмечал в своих трудах И.И. Лукашук, что «положения о ведомствах далеко не всегда четко определяют их компетенцию, особенно в области внешних сношений. Поэтому партнерам России непросто определять компетенцию соответствующего ведомства, и они могут предложить представить соответствующие полномочия» [5, с. 376].

Минюст России наделен правом выходить с предложениями по заключению международных договоров. Федеральный закон по данному вопросу в отношении международных межведомственных договоров говорит, что «предложения о заключении международных договоров Российской Федерации межведомственного характера представляются в Правительство Российской Федерации федеральными органами исполнительной власти или уполномоченными организациями по вопросам, входящим в их компетенцию, совместно с Министерством иностранных дел Российской Федерации или по согласованию с ним» [14, п. 4 ст. 9].

К сожалению, Министерство юстиции Российской Федерации, обладая правом внесения предложений о заключении международных договоров Российской Федерации любого уровня, участвуя в переговорах и составлении текста, не может напрямую внести в Государственную Думу соответствующий договор для его последующей ратификации. При этом, такими воз- 
можностями обладают государственные органы, являющиеся субъектами права законодательной инициативы, но не наделенные правом внесения предложений о заключении международных договоров. Возникшая с принятием закона о международных договорах правовая коллизия до сих пор не получила своего разрешения.

Рассматривая второе направление Министерства в процессе заключения международных договоров, отметим, что в соответствии с Федеральным законом Минюст России, как и другие отечественные министерства, вправе давать предложения о заключении международных договоров, как от имени Российской Федерации, так и Правительства. Однако, Положение о Минюсте России говорит, что «Министерство представляет в соответствии с законодательством Российской Федерации предложения о заключении и выполнении международных договоров Российской Федерации о правовой помощи и правовых отношениях по гражданским, семейным, уголовным и иным делам» [13, п/п. 22 п. 7]. Представление предложений о заключении международных договоров по иным вопросам Положением не предусмотрено. Практика складывается так, что международные договоры о правовой помощи и правовых отношениях заключаются от имени Российской Федерации [3; 4]. Таким образом, подзаконный акт, который должен дополнять и развивать положения Федерального закона, фактически сужает полномочия Минюста России в части внесения предложений о заключении международных договоров от имени Правительства Российской Федерации.

Также необходимо сказать, что в соответствии с пунктом 1 статьи 10 Федерального закона, Минюст России «согласовывает [курсив мой - А.К.] предложения о заключении международных договоров Российской Федерации, устанавливающих иные правила, чем предусмотренные законодательством Российской Федерации». Тем временем, в Положении о Минюсте России говорится, что Министерство «вносит [курсив мой - А.К.] в соответствии с законодательством Российской Федерации предложения о заключении международных договоров Российской Федерации, устанавливающих иные правила, чем предусмотренные законодательством Российской Федерации» [13, п/п. 24 п. 7].

Как мы видим, нормы Положения опять вступают в противоречие с Федеральным законом. По Федеральному закону инициаторами подобных предложений выступают иные органы по согласованию с Минюстом России, а по Положению - само Министерство юстиции. Необходимо отметить, что подобное противоречие отсутствовало до 2004 года. В предыдущем Положении о Министерстве юстиции, которое также было утверждено Указом Президента, говорилось, что Министерство юстиции Российской Федерации «согласовывает [курсив мой - А.К.] в установленном порядке предложения о заключении международных договоров Российской Федерации, устанавливающих правила, не предусмотренные законодательством Российской Федерации» [12, п/п. 52 п. 6]. Несмотря на то, что норма оперировала термином «согласовывает» вместо «вносит предложения», она тоже не была идеальна, так как говорила о правилах «не предусмотренных законодательством», вместо правил, противоречащих законодательству РФ.

Интерес для нашего исследования представляет и пункт 2 статьи 10 Федерального закона. Положения данного пункта гласят, что «Министерство юстиции Российской Федерации дает, в частности если это предусмотрено международным договором Российской Федерации или является необходимым условием вступления его в силу, заключения по вопросам соответствия положений договора законодательству Российской Федерации и их юридической силы в Российской Федерации, а также по иным вопросам, связанным с вступлением в силу и выполнением такого договора» [14].

Рассматриваемая норма относится, в том числе, к уже заключенным Российской Федерацией международным договорам, в отличие от пункта 1 той же статьи, которая охватывает только подлежащие заключению международные договоры.

Согласно терминологии, определенной в Федеральном законе, под международным договором Российской Федерации понимается «международное соглашение, заключенное Российской Федерацией с иностранным государством (или государствами), с международной организацией либо с иным образованием, обладающим правом заключать международные договоры... в письменной форме и регулируемое международным правом...» [14, п/п. а) ст. 2]. В свою очередь «заключение» представляет собой выражение согласия Российской Федерации на обязательность для нее международного договоpa [14, п/п. г) ст. 2]. Соответственно, пункт 2 статьи 
10 Федерального закона говорит о заключенных международных договорах, как действующих, так и не вступивших в силу.

Анализируя данную норму можно прийти к выводу, что Минюст России вправе давать заключения по вопросам соответствия положений договоров законодательству Российской Федерации и их юридической силы в Российской Федерации как по заключенным, так и незаключенным договорам, потому что в формулировке есть выражение «в частности».

Если мы обратимся к соответствующим правилам Положения, то опять обнаружим определенную несогласованность с нормами Федерального закона. В подпункте 25 пункта 7 Положения изменен порядок слов и исключено словосочетание «в частности», что значительным образом меняет смысл нормы. Согласно Постановлению, Министерство «дает заключения о соответствии положений международного договора Российской Федерации законодательству Российской Федерации и их юридической силе в Российской Федерации, а также по иным вопросам, связанным с вступлением в силу и выполнением такого договора, если это предусмотрено международным договором Российской Федерации или является необходимым условием вступления его в силу» [13, п/п. 25 ст. 7]. Таким образом, полномочия Минюста России по Постановлению опять сужены, так как покрывают только уже заключенные международные договоры. Получается, по Федеральному закону Министерство юстиции Российской Федерации вправе выдавать заключения, как по проектам международных договоров, так и по уже заключенным соглашениям, а по Постановлению - только в отношении последних и при условии, если это предусмотрено международным договором Российской Федерации или является необходимым условием вступления его в силу. Налицо очередная правовая коллизия, связанная с полномочиями российского Министерства.

Формально, ни Федеральный закон, ни подзаконные акты не дают Минюсту России полномочий воспрепятствовать заключению международного договора. Справедливо отмечает А. Г.Шатуновская-Бюрно, что «ни Министерство юстиции, ни МИД России не вправе давать субстантивный ответ, поэтому приходиться ограничиваться заключениями и объяснениями» [11, c. 132].

Говоря о полномочиях российских мини- стерств в отношении международных договоров, следует отметить, что Федеральный закон предоставляет всем им достаточно широкие полномочия, неизвестные министерствам и ведомствам в других государствах. Достаточно вспомнить отсутствие необходимости предъявления полномочий федеральными министрами при заключении международных договоров межведомственного характера. В отношении Министерства юстиции Российской Федерации эти полномочия еще шире исходя из его функциональной специфики. В то же время соответствующие подзаконные акты носят общих характер и не конкретизируют нормы Федерального закона, а зачастую вступают в противоречие с последним.

Как нормы Федерального закона, так и нормы действующего Положения, не предусматривают порядка согласования договоров, а также не ясно, можно ли вносить на рассмотрение президента или правительства предложение о заключении международного договора с отрицательным заключением. Соответственно, статус заключений Минюста России по вопросам международных договоров законодательно не определен. Все это дает основание говорить отечественным исследователям, что заключения Министерства юстиции Российской Федерации обладают консультативным или рекомендательным характером [1, комм. к ст. 10; 5, с. 501], при этом, они предназначены исключительно для внутреннего применения и для других участников международного договора юридического значения не имеют.

Подводя итог сказанному, отметим, что Федеральный закон «О международных договорах Российской Федерации» является основополагающим актом, регулирующим заключение, исполнение и прекращение международных договоров, в том числе определяет основные полномочия министерств и ведомств в этой сфере. Министерство юстиции Российской Федерации наделено существенными правами в процессе заключения международных договоров. Однако подзаконные акты, призванные конкретизировать и развить данные права, в полной мере с такой задачей не справляются. Например, статья 10 Федерального закона не получила своего логического развития в Положении о Минюсте России. Более того, возник целый ряд коллизий, которые в дальнейшем необходимо разрешать по общим правилам преодоления 
юридических коллизий.

Несмотря на все проблемы и противоречия, роль Министерства юстиции Российской Федерации в процессе заключения международных договоров трудно переоценить. Являясь уполномоченным государственным органом по нормативно-правовому регулированию в сфере юстиции, Минюст России может способствовать решению многих правовых задач, в том числе и международных. Рассмотрение проекта меж- дународного договора структурными подразделениями Министерства позволяет детально разобрать возможные правовые последствия такого договора и подготовить соответствующее заключение, что представляется особо важным для полноценного исполнения в будущем принимаемых договорных обязательств и реализации основополагающего принципа международного публичного права pacta sunt servanda.

\section{Библиографический список}

1. Агешкина Н.А. Научно-практический комментарий к Федеральному закону от 15 июля 1995 г. № 101 -ФЗ «О международных договорах Российской Федерации» / ИПС Консультант+.

2. Венская конвенция о праве международных договоров 1969 г. // Ведомости Верховного Совета СССР. 10 сентября 1986 г. № 37.

3. Договор между Российской Федерацией и Турецкой Республикой о взаимной правовой помощи по уголовным делам и выдаче. Анкара. 2014 // Собрание законодательства Российской Федерации. 14 августа 2014. № 33.

4. Конвенция между Российской Федерацией и Алжирской Народной Демократической Республикой о взаимной правовой помощи по уголовным делам. Алжир. 2017 // Собрание законодательства Российской Федерации. 17 июня 2019. № 24.

5. Лукашук И.И. Современное право международных договоров. В 2 т. Заключение международных договоров. М. 2004. Т. 1.

6. Приказ Министерства юстиции Российской Федерации от 27 января 2010 № 8 «Об утверждении Регламента Министерства юстиции Российской Федерации» // Бюллетень нормативных актов федеральных органов исполнительной власти. 29 марта 2010. № 13.

7. Соглашение между Министерством юстиции Российской Федерации и Министерством юстиции Республики Польша о порядке сношений по гражданским делам в рамках Договора между Российской Федерацией и Республикой Польша о правовой помощи и правовых отношениях по гражданским и уголовным делам от 16 сентября 1996 г. Санкт-Петербург. 2012 / ИПС Консультант+.

8. Соглашение о сотрудничестве между министерствами юстиции государств-членов Шанхайской организации сотрудничества. Душанбе. 2015 год / ИПС Консультант+.

9. Соглашение о сотрудничестве между Министерством юстиции Российской Федерации и Министерством юстиции Лаосской Народно-Демократической Республики. Москва. 2011 год / ИПС Консультант+.

10. Соглашение о сотрудничестве министерств юстиции государств-членов Евразийского экономического сообщества. Алматы. 2003 год / ИПС Консультант+.

11. Тиунов О. И., Манов Б. Г. Принцип соблюдения международных договоров: коллизии международного и национального права // Журнал российского права. 2008. № 6.

12. Указ Президента Российской Федерации от 02 августа 1999 № 954 «Вопросы Министерства юстиции Российской Федерации» // Собрание законодательства Российской Федерации. 09 августа 1999. № 32.

13. Указ Президента Российской Федерации от 13 октября 2004 № 1313 «Вопросы Министерства юстиции Российской Федерации» // Собрание законодательства Российской Федерации. 18 октября 2004. № 42.

14. Федеральный закон Российской Федерации «О международных договорах Российской Федерации» от 15 июля 1995. № 101-ФЗ // Собрание законодательства РФ. 17 июля 1995. № 29. 